\title{
Gênero e trabalho nos babaçuais maranhenses
}

\author{
Na terra das palmeiras: gênero, \\ trabalho e identidades no \\ universo das quebradeiras de \\ coco babaçu no Maranhão.
}

\section{BARBOSA, Viviane O.}

\section{Jundiaí: Paco Editorial, 2014.}

Os estudos de gênero vêm se ampliando no país, nas últimas décadas, e obtendo avanços consideráveis, tais como programas de pós-graduação específicos, a exemplo do PPG Mulheres, Gênero e Feminismo (UFBA); linhas de pesquisa sobre a temática em diversos programas de pósgraduação; grupos de trabalhos em associações científicas (ANPED, ANPOCS, ABEH, ALAS); periódicos dedicados à divulgação de pesquisas sobre gênero (a exemplo dos Cadernos Pagu, da Revista Estudos Feministas, do Caderno Espaço Feminino, da Revista Feminismo, da Revista Ártemis); eventos como Enlaçando Sexualidades, Seminário Internacional Fazendo Gênero, Colóquio Naciona Representações de Gênero e Sexualidade, Congresso Brasileiro de Estudos da Homocultura, Congresso Brasileiro de Pesquisadores Negros, Congresso Baiano de Pesquisadores Negros: publicações de livros, dissertações e teses.

Mesmo com essa ampliação, ainda são necessários estudos e publicações que procurem desvelar outras temáticas articuladas às discussões de gênero. Um desses temas diz respeito às mulheres do campo. É exatamente a discussão sobre gênero e etnicidade entre mulheres do campo, mais especificamente as quebradeiras de coco, que se dedica o livro de Viviane Barbosa,
Na terra das palmeiras: gênero, trabalho e identidades no universo das quebradeiras de coco babaçu no Maranhão.

O babaçu é uma cultura importante para a sobrevivência de milhares de famílias no Estado do Maranhão. As mulheres constituem cerca de $90 \%$ das trabalhadoras de quebradeiras de coco babaçu. Esse é um elemento que já justifica a realização de pesquisas que abordem as relações sociais de gênero em sua articulação com cor/etnia e classe.

O livro está organizado em cinco capítulos. Inicialmente, a autora apresenta as etapas da investigação, as principais categorias de análise e as questões teórico-metodológicas da pesquisa. Realizada em Monte Alegre, uma comunidade quilombola e distrito de São Luiz Gonzaga do Maranhão, a investigação contou com observação participante, entrevistas e análise de documentos e materiais produzidos pelo Movimento Interestadual das Quebradeiras de Coco Babaçu (MIQCB). Nesse primeiro capítulo, a autora também aborda as principais categorias teórico-analíticas selecionadas para compreender os dados construídos, considerando que é fundamental "analisar articuladamente relações de gênero e construção de identidades grupais/ coletivas, incluindo processos identitários étnicoraciais" (Viviane BARBOSA, 2014, p. 26).

Ainda nesse capítulo, a autora apresenta os conceitos de gênero, raça e classe com os quais busca compreender o universo das quebradeiras de coco. Articulando essa tríade, Barbosa procura fazer a discussão das identidades individuais e coletivas das entrevistadas.

No capítulo seguinte, a pesquisadora discute a importância do babaçu na história e economia do Maranhão, tendo em vista que esse Estado concentra $53 \%$ de toda a produção dessa palmeira no país. Valendo-se de sua 
formação como historiadora, Barbosa apresenta com detalhes de que forma o babaçu é inserido em terras maranhenses. Evidencia também as representações acerca da palmeira no Estado e, em particular, no município investigado, onde "identificou-se, por exemplo, que há no imaginário dos moradores de Monte Alegre a percepção da palmeira de babaçu como uma 'mãe', pois ela dá sustento, em outros termos, garante a sobrevivência, a vida" (BARBOSA, 2014, p. 72).

O terceiro capítulo aborda os conflitos sociais no campo, sendo uma realidade constante no Estado do Maranhão, principalmente em virtude da grilagem. Para a autora, "houve no estado, ao longo dos anos, uma combinação entre racionalização econômica, grilagem e modernização amparada por um projeto altamente autoritário por parte do Estado" (BARBOSA, 2014, p. 84). Ainda nesse capítulo, Barbosa evidencia o papel das mulheres no processo de negociação com os empresários na luta contra a derrubada das palmeiras:

No que concerne às quebradeiras, sua decisão em enfrentar restrições de fazendeiros/grileiros e suas iniciativas para empatar a derrubada de palmeiras, confrontando-se com proprietários, tomando a frente em muitas das negociações, incentivou a emergência expressiva de um movimento organizado. Aos poucos essas mesmas mulheres foram alcançando representatividade a partir de sua organização e concretizando algumas de suas demandas (BARBOSA, 2014, p. 105)

O capítulo quatro se propõe exatamente a mostrar de que forma as mulheres quebradeiras de coco babaçu se mobilizaram coletivamente por meio da criação do Movimento Interestadual de Quebradeiras de Coco Babaçu, um novo movimento social "cujas características são defesa ambiental e ecológica, afirmação da identidade étnica e demandas de gênero" (BARBOSA 2014, p. 107). Nessa seção, desenvolve sobre a forma como os chamados novos movimentos sociais do campo incluem na agenda das lutas por políticas públicas às suas demandas.

Tomando como exemplo as quebradeiras de coco, Barbosa aponta que esses novos movimentos sociais rurais agora se constituem identitariamente por meio da politização de termos locais e "os sujeitos passam a adotar como designação coletiva as denominações que utilizam para se definir e pelas quais são definidos cotidianamente, formando redes de organização" (BARBOSA, 2014, p. 109). A pesquisadora apresenta com detalhes a importância da mobilização política das quebradeiras de coco e as articulações dessas mulheres com a Igreja Católica e o poder público na luta pela preservação das palmeiras, bem como as conquistas daí advindas e de que forma as relações de gênero e as construções de identidades perpassam o dia-a-dia das mulheres quebradeiras de coco.

No último capítulo, Barbosa discute as relações de gênero e etnicidade entre as quebradeiras de coco babaçu do distrito pesquisado. Após descrever com detalhes a comunidade de Monte Alegre e seu cotidiano, a autora mostra, por meio das entrevistas realizadas, de que forma as representações e práticas, em torno do trabaIho, se articulam com as questões de gênero. Se a coleta do babaçu pode ser realizada por homens e mulheres, a quebra do coco é vista como atividade tipicamente feminina. Por mais que esse seja um discurso muito presente na comunidade, a autora aponta para algumas falas de mulheres que contrariam essa lógica. Do outro lado, "muitos homens que quebram coco não assumem que realizam essa atividade. Para muitos é relevante dizer que não praticam a atividade. Como não percebem essa tarefa como masculina, afirmarem-se como praticantes dela seria colocar em jogo sua própria masculinidade" (BARBOSA, 2014, p. 178).

A autora finaliza esse capítulo afirmando que, no caso dos trabalhadores rurais de Monte Alegre, ambos os gêneros reconhecem a importância do extrativismo para a manutenção da família. No entanto, relações mais próximas e subjetivas com as palmeiras são mantidas pelas mulheres, pois "o extrativismo é uma prática realizada, sobretudo, por elas, sendo associada ao feminino, o que não implica que homens mantenham tão somente relações materiais com as palmeiras" (BARBOSA, 2014, p. 199).

O livro é uma importante contribuição para os estudos de gênero entre as/os trabalhadoras/ es rurais. A riqueza descritiva e analítica do texto, aliada às articulações com o referencial teóricometodológico selecionado, auxilia na compreensão dos aspectos materiais e discursivos dos estudos de gênero. Ao pôr em evidência a maneira como gênero/raça/classe se configuram no caso específico da coleta do coco babaçu Barbosa nos faz pensar o quanto ainda precisamos conhecer/investigar as relações de trabalho e identidade étnica entre as mulheres negras quilombolas no país e no nordeste, em particular, tendo em vista ser esta a região do Brasil que concentra a maior parte das comunidades quilombolas reconhecidas como tal no país. 
[Recebida em 03/10/2016

e aceita em 07/02/2017]

Benedito Eugenio

Universidade Estadual do Sudoeste da Bahia Vitória da Conquista, Bahia, Brasil

Benedito Eugenio (beneditoeugenio@bol. com.br) é doutor em Educação (UNICAMP), professor da Universidade Estadual do Sudoeste da Bahia (UESB)-Campus de Vitória da Conquista, atuando na graduação, no Programa de Pós-
Graduação-Mestrado Acadêmico em Relações Étnicas e Contemporaneidade (PPGREC) e no Programa de Pós-Graduação em Ensino (PPGEN). Coordena, desde 2011, o Curso de Especializa-ção em Educação e Diversidade Étnico-cultural. Tem experiência na área de Educação, com ênfase em Currículos Específicos para Níveis e Tipos de Educação, atuando principalmente nos seguintes temas: currículo (políticas e práticas pedagógicas para a educação básica), educação das relações etnicorraciais, relações de raça e gênero na escola, políticas públicas e educação escolar quilombola. 